\title{
Engagement of politicians and citizens in the cyber campaign on Facebook: a comparative analysis between Mexico and Spain
}

\author{
Carlos Muñiz , Eva Campos-Domínguez , Alma Rosa Saldierna \& José Luis \\ Dader
}

To cite this article: Carlos Muñiz , Eva Campos-Domínguez , Alma Rosa Saldierna \& José Luis Dader (2017): Engagement of politicians and citizens in the cyber campaign on Facebook: a comparative analysis between Mexico and Spain, Contemporary Social Science, DOI: $10.1080 / 21582041.2017 .1367832$

To link to this article: http://dx.doi.org/10.1080/21582041.2017.1367832

Submit your article to this journal $\pi$

View related articles $\sqsubset \pi$

View Crossmark data $\nearrow$ 


\title{
Engagement of politicians and citizens in the cyber campaign on Facebook: a comparative analysis between Mexico and Spain
}

\author{
Carlos Muñiz (D) ${ }^{a}$, Eva Campos-Domínguez $\mathbb{D}^{\mathrm{b}}$, Alma Rosa Saldierna (iD ${ }^{\mathrm{a}}$ and José \\ Luis Dader (D) \\ aPolitical Comunication Lab, Universidad Autónoma de Nuevo León, San Nicolás de los Garza, Mexico; \\ ${ }^{\mathrm{b}}$ Modern, Contemporary and American History, Journalism, Audiovisual Communication and Publicity, \\ Universidad de Valladolid, Valladolid, Spain; 'Department of Journalism I, Universidad Complutense de \\ Madrid, Madrid, Spain
}

\begin{abstract}
This study explores the use of Facebook by political actors in election campaigns, establishing the extent to which candidates, parties and citizens engaged in online participation through different online tools provided by this social networking site. A comparative content analysis of the Facebook pages of the main candidacies in the election campaigns in Spain (Castilla y León) and Mexico (Nuevo León) in 2015 was carried out. The results reveal a positive relationship between types of engagement, especially in the Mexican campaign, where politicians and users score systematically higher in all variables measuring engagement. However, results also indicate that the citizen engagement was of higher quality/ intensity in the Spanish campaign.
\end{abstract}

\section{ARTICLE HISTORY}

Received 1 March 2017

Accepted 10 August 2017

\section{KEYWORDS}

Election campaigns; Internet; Facebook; political engagement; Spain; Mexico

\section{Introduction and context}

The new scenario propitiated by digital communication logically entails profound consequences in the field of political communication, as well as in the structuring of the democratic political debate itself. This article focuses on the study of Facebook, as a digital participation and information tool, in the context of the election cyber campaign. In this way, it is possible to observe how the candidates and the parties use this social networking sites (SNS) to get politically engaged with their followers (Muñiz, Dader, Téllez, \& Salazar, 2016). Using their Facebook profiles allows them to inform users about different issues related to the election campaign and discuss about them, which, eventually, is expected to contribute to the civic engagement of their followers by means of the tools that the SNS, and in this particular case, Facebook, place at their fingertips: options of clicking on likes, commenting on the posts and sharing them (Brandtzaeg \& Haugstveit, 2014).

The present study starts, as context, from the changes that have been occurring in the process of political cyber-communication in the last few years and it focuses on two analogous electoral campaign processes in 2015: one in Mexico and the other one in Spain. We assume that in these election campaigns 'communication of communities' plays a 
structuring, consolidating role in the communication strategy of parties and candidates, as classical emitters, and to the direct response and interaction that citizens can give to the messages sent by the former. The main objective of this paper is to determine whether the interaction between candidates and/or parties, which in the present article will be defined as candidacies, and their followers on the SNS Facebook occur through the means of the different engagement tools that Facebook puts at the disposal of both actors. In addition, we intend to determine, in a comparative manner, the similarities or differences existing between the two election campaigns developed in different political contexts.

\subsection{Election cyber campaigns}

Digital tools in election campaigns started out being a complementary, minority element rather than a real instrument to capture votes for political parties. Beginning by the webs, which were more focused on digital, self-promotion resources that reinforced the campaigns that were settled in, conceived and thought for traditional news media (Dader, Cheng, Campos-Domínguez, Quintana, \& Vizcaíno, 2014) and going up to the earliest tools of web 2.0, they all followed the strategy of the communication elites that had controlled mediatised politics for decades (Howard, 2006; McChesney, 2015; Norris, 2000; Ward, Gibson, \& Lusoli, 2008).

The first 'Internet candidates' appeared in the first decade of the twenty-first century (Vaccari, 2010) - such as Howard Dean (in 2004), Ned Lamont (in 2006) or Segolène Royal (in 2007) - who proved that the use of the Internet in their campaigns could make a great media impact. But it was doubtlessly Obama, with his 2008 campaign, who proved for the first time that the 'Internet candidate' could win elections (Delany, 2009; Hendricks \& Denton, 2010; Smith, 2010).

Although his success was initially attributed to the massive use of SNS, Obama's campaign showed that technological innovation as such was not the important issue, but rather the change in mentality in the strategic design of the cyber campaign (Delany, 2009). Following this tendency, in the last few years, authors have coined two alternative communicative paradigms for the new election campaigns: the hypothesis of innovation and the hypothesis of standardisation (Schweitzer, 2008, 2011, among others). The former (innovation) considers that there is a fundamental change in the way in which politics is presented to the public, one in which the electorate can participate and collaborate in the campaign itself (Kreiss, 2015, 2016; Kreiss \& Jasinski, 2016); the latter (standardisation), considers that cyber campaigns repeat the same type of strategies and practices of the offline world, failing to take advantage of the potentials offered by a change in mentality in the conception and planning of online campaigns.

\subsection{Political engagement 2.0 on Facebook}

Along this line, throughout the last century, there has been a debate that has faced the citizenry's ideals about the possibilities of cyber-politics to recover the power of democracy through, mainly, web 2.0, with reality. Low participation levels are nothing new and they have been chronic in a large part of the history of modern democracy. In this way, two schools have been intertwined since the onset of the Internet, propitiated by academic contributions (Shirky, 2011), but above all by political, media and citizen fascination 
for the scope of the new media, which defends that the effects of the network on democracy are predominantly positive. In such a way that the citizens, with technological advances, can organise much more effectively and establish networks of discussion, dissidence and even resistance in opposition to the traditional forms of power in some cases, according to the reports from the ranks of cyber-optimism (Benkler, 2011; Curran, 2012; Nielsen, 2012).

On the contrary, cyber-pessimists believe that fascination for the Internet and the new technologies do not only cause many harmful effects of the new media to be concealed; but also cause their role in very complex social and political processes to be systematically exaggerated, in contexts where the real incidence of the new technologies is, at best, anecdotic. Authors such as Morozov (2011) or Rendueles (2013) criticise the practical social demobilisation that is often masked behind the cyber-fetishism of permanent connection.

These studies, which contextualise the importance of civic and political engagement, have come to resituate the importance acquired in the last few years by the need to involve the citizens with the politics gestated on the Internet and the response that the politicians assume in this scenario. This research includes part of the literature that has been published in the last few years about engagement (Andersen \& Hansen, 2007; Dahlgren, 2011; Delli Carpini, 2004; Delli Carpini, Cook, \& Jacobs, 2004, Túñez \& Sixto, 2011, among others) and political engagement or political engagement 2.0, just as defined by Muñiz et al. (2016), as in the work that evaluates the degree to which the candidates engage with the citizens through the SNS interacting with them beyond simple messages of thanks and the dissemination of personal and campaign information. Thus, we understand political engagement 2.0 as the commitment that, through debate and deliberation, politicians establish with the citizens on the SNS.

Within the studies that focus on the new media as channels for political engagement on the Internet and its effects, Facebook has concentrated a large part of the analyses because, just as defined by Conroy, Feezell, and Guerrero (2012), it allows the users to interact at different levels with other users by means of the exchange of information about themselves and to share the information, and thus interact with the messages that other users publish on their pages. Although other SNS, such as Twitter, have surfaced in election campaigns, Facebook is considered the largest SNS since 2011 as well as the most popular among users (Brandtzaeg, 2017; Woolley, Limperos, \& Oliver, 2010).

The importance of Facebook as a tool in election campaigns to promote political communication was demonstrated in Barack Obama's 2008 campaign (Hanson, Haridakis, Cunningham, Sharma, \& Ponder, 2010; Larsson \& Kalsnes, 2014; Williams \& Gulati, 2013). Just as Muñiz et al. (2016) point out, it is considered that this campaign proved the potential of this SNS to plan the candidate's strategies (Woolley et al., 2010). Perhaps the greatest use that candidates make of this SNS in the elections can be explained by the excellent interaction tools that it provides for its users, which reflect the citizens' civic engagement on the online field, according to authors such as Brandtzaeg and Haugstveit (2014). There are various kinds of instruments ranging from low-cost tools, such as clicking on like on a page or publication, to others such as writing comments or sharing publications, which reflect a stronger commitment on the part of the user. 


\subsection{Political and cultural context of study}

This study analyses the use that candidates and citizens make of the SNS in two elections that occurred in the same period (the first semester of 2015), and that took place in two different regions or states of Mexico and Spain. Both countries offer different political systems (Mexico has a presidential system, while Spain has a parliamentary system), and political cultures, so that a comparative approach can help us understand how Facebook serves as a political communication tool in two very different case studies. Our research goal is therefore to explore the possibilities that Facebook offers as a political communication tool in two election campaigns, to find out how politicians use this SNS and their political engagement 2.0, what issues they propose in their posts and how the followers respond to these messages.

In the Spanish case, we study the cyber campaign in Castilla y León, the largest autonomous community in Spain. The use of the Internet in Spanish election campaigns has been studied before, but this is one of the least explored regions (Dader \& Campos-Domínguez, 2016). Although the political life of Castilla y León had been monopolised by the two main national parties (PP and PSOE), the 2015 elections opened a gap in the two-party system, when it allowed the arrival of new parties in the region's political panorama. For the Mexican case, we studied the Nuevo León cyber campaign, a relatively small community in terms of both extension and population, but one of the most important regions in terms of its economic and corporate levels within Mexico. The 2015 state campaign presupposed a rupture in the traditional two-party system enthroned by the main political parties in the country (PRI and PAN), when the winner of the governor elections was an independent candidate. Coincidentally, this was a candidate who concentrated a large part of his campaign on the SNS. Taking all this into account, the study intends to answer the following research questions:

RQ1: Were there differences at the level of political engagement 2.0 and civic engagement on the candidacies' Facebook pages in both election campaigns?

RQ 2: Were there associations between both types of engagements on the candidacies' Facebook pages in both election campaigns?

RQ 3: Were there differences in the issues dealt with in the candidacies' Facebook pages of both election campaigns?

\section{Method}

\subsection{Sample and reliability of the study}

To answer the research questions posed, a content analysis of the posts published on the candidacies' Facebook pages of the two election campaigns was carried out, one for Mexico and the other one for Spain, which had been selected because they are relatively simultaneous and comparable. For this study, we used each candidacy's Facebook page as context units. All the posts published by these candidates during the campaign on their Facebook walls were selected. We only selected and analysed the messages that had been directly written by the party's or the candidate's campaign team. To capture the posts and the comments made in respect of those publications, the software application NCapture for Google Chrome provided by NVivo was used. 
In the case of Spain, we coded the posts $(N=346)$ published by the following parties or candidates in the Castilla y León elections, who had their own Facebook pages: People's Party (PP) ( $n=65)$, Socialist Party (PSOE) $(n=95)$, Podemos $(n=51)$, United Left (IU) $(n=$ $65)$, Citizens $(n=12)$ and Union, Progress and Democracy (UPyD) $(n=58)$. The time frame of the study was limited to the 15 days of election campaign (that is, when political parties are officially allowed to campaign in Spain), plus the reflection days (from 8 to 23 May 2015).

In the case of Mexico, we selected the posts $(N=485)$ published by the candidates that were most likely to win the elections according to polls published during the election campaign: Felipe de Jesús Cantú (National Action Party, PAN) $(n=387)$, Ivonne Álvarez (Institutional Revolutionary Party, PRI) $(n=45)$ and Jaime Rodríguez 'el Bronco' (Independent) $(n=53)$. Because the three-month duration of this election campaign posed a problem for comparison with the Spanish case, only the last two weeks of the campaign were analysed (from 25 May to 4 June 2015), including the reflection days.

The coding process of the set of posts selected in both elections $(N=831)$ was carried out by eight coders in Spain and six in Mexico. A new analysis was performed on $20 \%$ of the total number of analysis units $(n=166)$ to calculate inter-rater reliability, and a mean value of Krippendorff's alpha of .79 was obtained.

\subsection{Codebook}

Political engagement 2.0 of candidacies: To measure the level of political engagement 2.0 developed by candidates and/or parties on their Facebook pages, the scale developed by Muñiz et al. (2016) was used. This scale utilises four variables that measure both the quantity and quality of the participation and contributions to knowledge of users developed by the candidates through providing new information from the original post. The four variables considered were added to generate an indicator of political engagement 2.0, which presented reliability for both the global samples $(a=.97)$, and in the two countries covered: Mexico $(a=.97)$ and Spain $(a=.96)$.

Engagement of network users: To evaluate the level of engagement reflected by users, three variables were evaluated. These variables have been considered by Brandtzaeg and Haugstveit (2014) as interaction tools provided by Facebook to facilitate civic engagement. In particular, the number of times a post received likes was analysed for each, as well as the number of times it was shared and the number of times it was commented on.

Issues addressed in the posts by the candidacies: As to the issues, the coders were asked to determine whether the posts analysed mentioned or referred to $(1=$ yes, $0=$ no) several aspects referred to: 'processes of a civic-political/institutional nature' (e.g. inauguration or protest, honours to the flag, etc.); 'general-interest social issues' (e.g. allusions to sports success or meetings with citizen associations or groups); 'general political issues' (e.g. addressing issues beyond the proposals by parties and candidates); 'political-ideological nature' (e.g. those posts in which the ideological-propaganda approach prevailed or that expressed values or defended models of society in the abstract). On the other hand, it also coded whether the post referred to 'platform or political proposals' presented by the candidate or party posting messages on Facebook, to 'platform or political proposals' concerning rival candidates or parties, whether mentioned 'personal or informative issues about the campaign activity' of the candidate or the party who posted on Facebook 
and, finally, whether the post referred to 'personal or informative issues about the campaign activity', but in this case about rival candidates or parties.

\section{Results}

In the first phase of the data analysis, it was decided to contrast to what extent there were differences between the candidacies of each election compared in terms of the level of political engagement 2.0 developed by them on their Facebook pages. The results revealed statistically significant differences between both countries, $t(517)=12.870, p$ $<.001, d=0.83$. In this sense, it is possible to observe clearly how the level of political engagement 2.0 of the Mexican candidacies was evidently greater $(M=1.46, E D=2.41)$ than that of their Spanish counterparts $(M=0.03, E D=0.38)$. These results are similar to those obtained in relation to the level of engagement maintained by the users of Facebook pages of the candidacies during the election campaigns. For the three analysed variables of citizen engagement (the number of likes, the number of comments and the number of times the candidacy posts were shared), Mexican users scored higher, showing that they were more involved in the candidacy strategy on the social network, developing a greater level of interaction with the candidates (see Table 1).

Regarding the number of likes, the differences observed were statistically significant and strong, $t(484)=12.028, p<.001, d=0.77$. In this sense, as opposed to an average of 2905.18 likes $(E D=5277.61)$ for each post published on the Mexican Facebook pages, in the Spanish case, it was only possible to observe an average interaction of 22.64 likes $(E D=20.97)$. The second engagement variable with the greatest difference in its use between the two samples was the one related to the number of times the candidacy post was commented on by the followers, $t(483)=10.075, p<.001, d=0.65$. Once again, it is possible to observe how in the Mexican case, the users of the candidacies' Facebook pages developed a greater involvement $(M=169.10, E D=368.21)$ than what can be observed in the Spanish case $(M=0.64, E D=1.39)$. Finally, the smallest differences were found regarding the number of times that the post was shared by the network users, because even though the difference was also statistically significant, this difference was moderate, $t(484)=4.486, p<.001, d=0.29$. Once again, the Mexican sample revealed greater interactivity, Mexican users shared the candidacy posts more often $(M=509.65$, $E D=2473.65)$ than the users in the Spanish sample $(M=5.71, E D=10.82)$ (see Table 1$)$.

To delve in the relations between the different engagement variables measured, order 0 correlations tests were performed among the study's variables, with the aim of

Table 1. Differences in the means in terms of political engagement 2.0 of the candidacies and users' engagement (standard deviation in parentheses).

\begin{tabular}{|c|c|c|c|c|c|c|c|}
\hline \multirow[b]{2}{*}{ Measures } & \multicolumn{2}{|c|}{ Reference state } & \multirow[b]{2}{*}{$t(\mathrm{df})$} & \multirow[b]{2}{*}{$p$} & \multicolumn{2}{|c|}{$95 \% \mathrm{Cl}$} & \multirow[b]{2}{*}{$d$} \\
\hline & $\begin{array}{l}\text { Mexico } \\
(n=485)\end{array}$ & $\begin{array}{l}\text { Spain } \\
(n=346)\end{array}$ & & & LL & UL & \\
\hline Political engagement 2.0 & $1.46(2.41)$ & $0.03(0.38)$ & $12.870(517)$ & $<.001$ & 1.216 & 1.654 & 0.83 \\
\hline Number of likes & $2905.18(5277.61)$ & $22.64(20.97)$ & $12.028(484)$ & $<.001$ & 2411.661 & 3353.413 & 0.77 \\
\hline Number of times it was shared & $509.65(2473.65)$ & $5.71(10.82)$ & $4.486(484)$ & $<.001$ & 283.238 & 724.643 & 0.29 \\
\hline $\begin{array}{l}\text { Number of times it was } \\
\text { commented on }\end{array}$ & $169.10(368.21)$ & $0.64(1.39)$ & $10.075(484)$ & $<.001$ & 135.602 & 201.307 & 0.65 \\
\hline
\end{tabular}

Notes: $N=831$. Cl: confidence interval for the difference; LL: lower limit; UL: upper limit. 
determining the level of association among them and the differences existing between the two samples studied. As it can be observed in the data provided by Table 2, all the correlations were statistically significant for both countries, but not in all the cases were similar effect sizes presented. Thus, it is observed how the level of political engagement 2.0 tended to co-vary positively with the number of likes given by Facebook users, both in the case of Mexico $(r[483]=.358, p<.001)$ and in the case of Spain $(r[344]=.111, p$ $=.040$ ). This association in the Spanish candidacies was clearly greater than those of Mexican candidacies, $Z=3.72, p<.001$. The same occurred in the case of the association between political engagement 2.0 and the number of times the posts were commented on, $Z=2.33, p=.020$. This level of interaction was clearly greater in the case of Mexico ( $r$ $[483]=.387, p<.001)$ than in the case of Spain $(r[344]=.239, p<.001)$. However, no differences were found between the correlations of political engagement 2.0 and the number of times the posts were shared, $Z=0.49, p=.624$, and it was the least level of interaction detected in both countries between the variables candidacies' engagement and their followers.

It is interesting to observe how, when analysing the relations between the civic engagement variables, different patterns are detected between both samples (see Table 2). In the case of Mexico, it can be noticed that the greatest level of association occurred between the action of clicking on like on the candidacy's post and the action of making a comment on that post published $(r[483]=.769, p<.001)$. This relation appeared as the dominant one in this sample as opposed to what was observed in the Spanish case, $Z=8.33, p<.001$. However, the sample from the Spanish election campaign showed a greater behaviour pattern on Facebook tending to click on like on the candidacy posts, while they shared them on their own wall $(r[344]=.672, p<.001)$. An activity that clearly dominated the same behaviour detected in the Mexican sample, $Z=5.73, p<.001$. However, the behaviour pattern tending to share at the same time they comment on the posts did not show differences between both samples, $Z=0.49, p=.624$, in addition, it was the one that showed the least strength for both countries.

Finally, with respect to understanding the type of contents that were transmitted by the candidacies on their Facebook publications, the presence of the eight issues included in the analysis was compared (see Table 3). To perform the hypothesis contrasts, Fisher's exact test was used, when working with $2 \times 2$ contingency tables, providing in addition

Table 2. Correlations between variables of candidacies' political engagement and followers' engagement by country.

\begin{tabular}{|c|c|c|c|c|c|}
\hline Country & Measures & 1 & 2 & 3 & 4 \\
\hline \multirow{4}{*}{$\begin{array}{l}\text { Mexico } \\
\quad(n=485)\end{array}$} & Political engagement 2.0 & \multirow[t]{4}{*}{-} & $.358^{* * *}$ & $.127^{* *}$ & $.387^{* * *}$ \\
\hline & Number of likes & & - & $.388^{* * *}$ & $.769 * * *$ \\
\hline & Number of times shared & & & - & $.343^{* *}$ \\
\hline & Number of times it was commented on & & & & - \\
\hline \multirow{4}{*}{$\begin{array}{l}\text { Spain } \\
\qquad(n=346)\end{array}$} & Political engagement 2.0 & \multirow[t]{4}{*}{-} & $.111^{*}$ & $.161^{* *}$ & $.239 * * *$ \\
\hline & Number of likes & & - & $.672^{* * *}$ & $.405^{* * *}$ \\
\hline & Number of times shared & & & - & $.373^{* * *}$ \\
\hline & Number times it was commented on & & & & - \\
\hline
\end{tabular}

Note: $N=831$.

${ }^{*} p<.05$.

${ }^{* *} p<.01$.

${ }^{* * *} p<.001$. 
Table 3. Differences in terms of the presence of each issue in the candidacy posts (percentage).

\begin{tabular}{lrrrr}
\hline & \multicolumn{3}{c}{ Reference state } \\
\cline { 2 - 3 } Issues of the posts published & Mexico & \multicolumn{2}{c}{ Spain } & \\
\hline Processes of a civic-political/institutional nature & $(n=485)$ & $(n=346)$ & $p$ & $\pi$ \\
General-interest social issues & 4.3 & 11.3 & $<.001$ & .133 \\
General political issues & 10.5 & 14.5 & .086 & .060 \\
Political or platform proposals of the candidate or party who posts & 28.7 & 29.5 & .816 & .009 \\
Political or platform proposals of rival candidates or parties & 9.3 & 35.3 & $<.001$ & .320 \\
Personal or informative issues of the candidate or party who posts & 0.6 & 6.9 & $<.001$ & .176 \\
Personal or informative issues about the activity of rival candidates or parties & 8.0 & 62.4 & $<.001$ & .581 \\
Comments with a political-ideological nature & 1.9 & 6.4 & $<.001$ & .117 \\
\hline
\end{tabular}

Notes: $N=831$. Only the positive values are reported, that is, the percentage of favourable answers to the presence of each issue in the posts analysed.

Cramer's phi value to determine effect size. It was possible to find statistically significant differences for the use of all of them, except for the case of the posts about 'general-interest social issues' ( $p=.086, \pi=.060$ ), present in $10.5 \%$ of the Mexican posts and $14.5 \%$ of the Spanish posts. Nor any differences were found with respect to the presence of 'general political issues' ( $p=.816, \pi=.009)$, an issue that had a $28.7 \%$ presence in the Mexican candidacies and $29.5 \%$ of the Spanish ones.

As it can be observed in Table 3, the use of Facebook by the Spanish candidacies was more varied in terms of the use of the different issues analysed. Thus, on their Facebook publications, they tended to present more issues related to 'processes of a civic-political and/or institutional nature' $(11.3 \%, p<.001, \pi=.133)$ and 'comments of a political-ideological nature' $(53.2 \%, p<.001, \pi=.383)$. On the other hand, it was also coded whether the candidacies tended to launch or transmit 'political or platform proposals' regarding the candidate or the party who posted the message in their publications on the SNS studied. In this regard, statistically significant differences were found, $p<.001, \pi=.320$, and the presence of these proposals clearly dominated in the case of the Spanish posts (35.3\%) as opposed to the Mexican ones (9.3\%).

A similar result was detected with respect to the allusion of 'political or platform proposals' but those were generated by rival candidates or parties, $p<.001, \pi=.176$. In both countries, the presence of this type of allusions was lower, but at any rate, the Spanish sample dominated (6.9\%) as opposed to the Mexican one $(0.6 \%)$. Finally, differences were also found with respect to the reference to 'personal or informative issues of the candidate or party who posts' on Facebook, $p<.001, \pi=.581$. Once again, the difference was big with Spain dominating in this type of publications (62.4\%) as opposed to Mexico (8.0\%). And regarding the references to 'personal or informative issues of the activity' concerning rival candidates or parties $(p<.001, \pi=.117)$, Spanish posts scored higher $(6.4 \%)$ than the Mexican ones (1.9\%).

\section{Conclusions}

The results of the study conducted reveal the importance Facebook has as a tool for interaction among candidates and/or parties and their followers during election campaigns. Starting from the evaluation of the level of engagement developed on the SNS by both actors, it has been possible to confirm that the more engagement showed by political actors, the more civic engagement is to be found among the followers. So, it is possible 
to note that an increase in candidate's and/or party's involvement may contribute to an increase in citizen participation, at least in the online arena.

As an answer to the first question, there were clear-cut differences between both campaigns studied. Whereas in the Spanish campaign the development of political engagement 2.0 was almost anecdotic among the candidacies and very low that of the users, the Mexican campaign appeared as a stage where there was a solid online participation of its different actors. Beyond the fact that in the Nuevo León (Mexico) campaign, there was a candidate who used the SNS proficiently, who in addition eventually won the elections, the involvement of Facebook as a space for cyber campaigns was strong in all the candidates.

Answering the second research question, this was reflected in the strong associations between the engagement of the candidacies and that of the users, where again the Mexican case was the dominant one. It was observed that in both countries, the benefit of the candidacies' political engagement 2.0 redounded more to users' low- or mediumcost engagement levels, such as clicking on like or commenting the post published by the politicians. Therefore, it is observed that it is still complicated for a large part of the citizens to become strongly engaged on SNS, by means of actions that involve a greater level of involvement with the candidacies, such as sharing the politicians' posts and, somehow, assume their comments as their own and become their spokespersons.

Nevertheless, the analysis of the associations among the different variables that make up civic engagement of Facebook users revealed an important difference between both countries. Although in general terms the followers of candidacy pages in Mexico showed greater levels of online civic engagement, it was observed that the quality of the Spanish followers' engagement was greater. That is revealed by the fact that two different patterns of engagement were present in each country. While in Mexico users were very active on their Facebook pages by means of low and medium engagement actions, such as clicking on like and commenting on the candidacy posts, in Spain users were less active on Facebook pages, but their involvement derived into medium and high engagement actions, such as sharing at the same time as they liked the posts by their candidacies.

It is very likely that these differences in citizen engagement derive from the different engagement activities deployed by political actors on Facebook pages. Answering the third question, there was greater thematic variety in the Spanish posts, as opposed to Mexico. Except in general issues of political or social nature, where there were no differences, in all the other issues the Spanish candidacies dominated. This could have led to the fact that their followers became more involved by means of high engagement actions, such as sharing the candidacy posts, since the debate developed on the Spanish Facebook pages was more political-ideological than strategic. At any rate, there are tasks pending such as determining whether the strategy followed by the Mexican candidates had more of an impact on mobilisation through dialogue in the subsequent posts, and not so much in the transmission of platform campaign contents of their posts on their walls.

\section{Acknowledgement}

The authors thank the project's research team for their coding work, and the anonymous reviewers for their valuable comments. 


\section{Disclosure statement}

No potential conflict of interest was reported by the authors.

\section{Funding}

The research that was the basis for this article was financed with a project of the Ministerio de Economía y Competitividad of the Spanish Government [grant number CSO2013-44446-R], of the Universidad Autónoma de Nuevo León [grant number PAICYT-CSH012-15] and the Consejo Nacional de Ciencia y Tecnología (CONACYT) [grant number 232842] from Mexico.

\section{Notes on contributors}

Carlos Muñiz holds a PhD in communication and is Tenured Professor at Universidad Autónoma de Nuevo León (Mexico). His research line focuses on media effects in political communication area and frame analyses.

Eva Campos-Domínguez holds a $\mathrm{PhD}$ in communication and is Professor of Journalism at Universidad de Valladolid (Spain). Her research line focuses on digital political communication and technological innovations applied to communication.

Alma Rosa Saldierna holds a PhD specialised in political sciences and is Full Professor at the Universidad Autónoma de Nuevo León (Mexico). Her research line focuses on political behaviour and political attitudes.

José Luis Dader holds a PhD in information sciences and is Professor and at the Universidad Complutense de Madrid (Spain). His research line focuses on political communication, journalistic professionalism and precision journalism, and the use of the Internet in political communication.

\section{ORCID}

Carlos Muñiz (1) http://orcid.org/0000-0002-9021-8198

Eva Campos-Domínguez (D) http://orcid.org/0000-0002-8970-7947

Alma Rosa Saldierna (i) http://orcid.org/0000-0003-1805-9740

José Luis Dader (D) http://orcid.org/0000-0001-7354-5587

\section{References}

Andersen, V. N., \& Hansen, K. M. (2007). How deliberation makes better citizens: The Danish deliberative poll on the Euro. European Journal of Political Research, 46(4), 531-556. doi:10.1111/j.14756765.2007.00699.x

Benkler, Y. (2011). The penguin and the leviathan: How cooperation triumphs over self-interest. New York, NY: Crown Business.

Brandtzaeg, P. B. (2017). Facebook is no 'great equalizer': A big data approach to gender differences in civic engagement across countries. Social Science Computer Review, 35(1), 103-125. doi:10.1177/ 0894439315605806

Brandtzaeg, P. B., \& Haugstveit, I. M. (2014). Facebook likes: A study of liking practices for humanitarian causes. International Journal of Web Based Communities, 10(3), 258-279. doi:10.1504/IJWBC. 2014.062942

Conroy, M., Feezell, J. T., \& Guerrero, M. (2012). Facebook and political engagement: A study of online political group membership and offline political engagement. Computers in Human Behavior, 28, 1535-1546. doi:10.1016/j.chb.2012.03.012

Curran, J. (2012). Reinterpreting the internet. In J. Curran, N. Fenton, \& D. Freedman (Eds.), Misunderstanding the internet (pp. 3-33). Abingdon: Routledge. 
Dader, J. L., \& Campos-Domínguez, E. (Eds.). (2016). La cibercampaña en Castilla y León. Elecciones autonómicas, 2015. Valladolid: Universidad de Valladolid.

Dader, J. L., Cheng, L., Campos-Domínguez, E., Quintana, N., \& Vizcaíno, R. (2014). Las webs de los partidos españoles en campaña electoral. Continuismo entre 2008 y 2011. Trípodos, 34, 115152. Retrieved from http://www.tripodos.com/index.php/Facultat_Comunicacio_Blanquerna/ article/download/169/255

Dahlgren, P. (2011). Media and political engagement. Citizens, communication and democracy. Cambridge: University Press.

Delany, C. (2009). Learning from Obama: Lessons for online communicators in 2009 and beyond. Retrieved from www.epolitics.com/learning-from-obama.pdf

Delli Carpini, M. (2004). Mediating democratic engagement: The impact of communications on citizens' involvement in political and civic life. In L. L. Kaid (Ed.), Handbook of political communication research (pp. 395-434). New York, NY: Lawrence Erlbaum Associates.

Delli Carpini, M. X., Cook, F. L., \& Jacobs, L. R. (2004). Public deliberation, discursive participation, and citizen engagement: A review of the empirical literature. Annual Review of Political Science, 7, 315344. doi:10.1146/annurev.polisci.7.121003.091630

Hanson, G., Haridakis, P. M., Cunningham, A. W., Sharma, R., \& Ponder, J. D. (2010). The 2008 presidential campaign: Political cynicism in the age of Facebook, MySpace, and YouTube. Mass Communication and Society, 13(5), 584-607. doi:10.1080/15205436.2010.513470

Hendricks, J. A., \& Denton, R. (2010). Political campaigns and communicating with the electorate in the twenty-first century. In J. A. Hendricks \& R. Denton (Eds.), Communicator-in-Chief: How Barack Obama used new media technology to win the white house (pp. 1-18). Lanham, MD: Lexington Books.

Howard, P. (2006). New media campaigns and the managed citizen. New York, NY: Cambridge University Press.

Kreiss, D. (2015). Digital campaigning. In D. Freelon \& S. Coleman (Eds.), Handbook of digital politics (pp. 118-135). New York, NY: Edgar Elgar.

Kreiss, D. (2016). Prototype politics: Technology-intensive campaigning and the data of democracy. Oxford: Oxford University Press.

Kreiss, D., \& Jasinski, C. (2016). The tech industry meets presidential politics: Explaining the Democratic Party's technological advantage in electoral campaigning, 2004-2012. Political Communication, 13, 1-19. doi:10.1080/10584609.2015.1121941

Larsson, A. O., \& Kalsnes, B. (2014). 'Of course we are on Facebook': Use and non-use of social media among Swedish and Norwegian politicians. European Journal of Communication, 29(6), 653-667. doi:10.1177/0267323114531383

McChesney, R. W. (2015). Digital disconnect: How capitalism is turning the internet against democracy. New York, NY: The New Press.

Morozov, E. (2011). The net delusion: The dark side of internet freedom. New York, NY: Public Affairs.

Muñiz, C., Dader, J. L., Téllez, N. M., \& Salazar, A. (2016). Are politicians politically engaged? Analysis of the political engagement 2.0 developed through Facebook. Cuadernos.info, 39, 135-150. doi:10. $7764 /$ cdi.39.970

Nielsen, M. (2012). Reinventing discovery: The new era of networked science. Princeton, NJ: Princeton University Press.

Norris, P. (2000). A virtuous circle. Cambridge: Cambridge University Press.

Rendueles, C. (2013). Sociofobia. El cambio político en la era de la utopía digital. Madrid: Capitán Swing.

Schweitzer, E. J. (2008). Innovation or normalization in E-campaigning? A longitudinal content and structural analysis of German party websites in the 2002 and 2005 national elections. European Journal of Communication, 23(4), 449-470. doi:10.1177/0267323108096994

Schweitzer, E. J. (2011). Normalization 2.0: A longitudinal analysis of German online campaigns in the national elections 2002-9. European Journal of Communication, 26(4), 310-327. doi:10.1177/ 0267323111423378

Shirky, C. (2011). The political power of social media. Foreign Affairs, 90(1), 28-41. 
Smith, M. (2010). Political campaigns in the twenty-first century: Implications of new media technology. In J. A. Hendricks \& R. Denton (Eds.), Communicator-in-Chief: How Barack Obama used new media technology to win the White House (pp. 139-155). Lanham, MD: Lexington Books.

Túñez, M., \& Sixto, J. (2011). Social networks, politics and commitment 2.0: Spanish MPs on Facebook. Revista Latina de Comunicación Social, 66, 210-234. doi:10.4185/RLCS-66-2011-930-210-234

Vaccari, C. (2010). 'Technology is a commodity': The internet in the 2008 United States presidential election. Journal of Information Technology \& Politics, 7, 318-339. doi:10.1080/19331681003656664

Ward, S., Gibson, R., \& Lusoli, W. (2008). The United Kingdom: Parties and the 2005 virtual campaign - not quite normal? In S. Ward, D. Owen, R. Davis, \& D. Taras (Eds.), Making a difference: A comparative view of the role on the internet in election politics (pp. 132-160). Lanham, MD: Lexington Books.

Williams, C. B., \& Gulati, G. J. (2013). Social networks in political campaigns: Facebook and the congressional elections of 2006 and 2008. New Media and Society, 15, 52-71. doi:10.1177/ 1461444812457332

Woolley, J. K., Limperos, A. M., \& Oliver, M. B. (2010). The 2008 presidential election, 2.0: A content analysis of user-generated political Facebook groups. Mass Communication and Society, 13(5), 631-652. doi:10.1080/15205436.2010.516864 